\title{
Organizacja i rozwój Katedry Dydaktyki Polonistycznej (w sześćdziesiątą rocznicę powstania)
}

\author{
Organisation and development \\ of the Department of Polish Didactics \\ (on its 60th anniversary)
}

\begin{abstract}
Summary: The author presents the beginnings and development of the Department of Polish Didactics (Chair of Linguistic Didactics and Polish Literature) which has been functioning for 60 years. She describes the development of language and literature didactics as separate scientific disciplines. She draws attention to the dynamic activity of Mitera-Dobrowolska, who had a special contribution not only to the formation of the later Chair, but also to the development of many generations of teachers of Polish and subject methodologies.
\end{abstract}

Keywords: Department of Polish Didactics (Chair of Linguistic Didactics and Polish Literature), language didactics, didactics of Polish literature

Wyjdźmy od prawdy oczywistej, że II wojna światowa zniszczyła przedwojenne struktury oświatowo-szkolne i zdziesiątkowała kadrę nauczycielską. $\mathrm{Ci}$, którzy przeżyli zamierzoną przez okupanta eksterminację polskiej inteligencji, organizowali ofiarnie tajne nauczanie, od stopnia podstawowego aż po akademickie, a po wyzwoleniu włączali się aktywnie w odbudowę szkolnictwa na wszystkich jego szczeblach. Brakowało jednakże kadry pedagogicznej, toteż w różnych regionach kraju organizowano placówki kształcące i dokształcające nauczycieli. Problem ten zaznaczył się szczególnie wyraźnie na Górnym Śląsku, gdzie już przed wojną brakowało nauczycieli. Na tym obszarze trzon kadry 
pedagogicznej stanowili absolwenci uniwersytetów z Krakowa i z Poznania, którzy przybywali na te ziemie głównie ze względów ideowo-patriotycznych.

Już w drugiej połowie lat czterdziestych minionego stulecia powstały zatem w Katowicach instytucje, które miały tę lukę zapełnić. Były to: Liceum Pedagogiczne, Wyższe Kursy Nauczycielskie oraz Instytut Pedagogiczny ${ }^{1}$, a od roku 1950 - Wyższa Szkoła Pedagogiczna². Jej kadrę profesorską w dużej mierze stanowili przedwojenni doktorzy z dużymi osiągnięciami zarówno w szkolnictwie średnim Śląska, jak i w nauce, którzy po wojnie uzyskiwali docentury. Dopełniali tę kadrę nauczyciele akademiccy dojeżdżający z Krakowa. Młodsi pracownicy rekrutowali się początkowo z absolwentów Uniwersytetu Jagiellońskiego, następnie zatrudniano własnych wychowanków. Powstaniu uczelni humanistycznej w okręgu przemysłowym przypisywano szczególną rolę. Zwłaszcza Wydział Filologiczno-Historyczny (taką nazwę nosił przez pierwsze lata istnienia) stanowił wówczas jeden z istotnych ośrodków myśli humanistycznej i kultury na Górnym Śląsku.

Głównym zadaniem tej uczelni — podobnie jak innych wyższych szkół pedagogicznych, które powstawały w tym czasie w wielu miastach naszego kraju — było dostarczenie szkołom wykształconej nowocześnie kadry nauczycielskiej. Zdobywana przez studentów wiedza kierunkowa zyskiwała w wyższych szkołach pedagogicznych rzetelną nadbudowę w postaci rozbudowanych przedmiotów psychologiczno-pedagogicznych oraz metodyk przedmiotowych i praktyk pedagogicznych, do których przywiązywano dużą wagę. W wyniku szeroko zakrojonych celów kształcenia przyszłych nauczycieli polonistów doc. dr Mieczysława Mitera-Dobrowolska utworzyła w roku 1958 Zakład, a rok później - Katedrę Metodyki Nauczania Literatury i Języka Polskiego w katowickiej WSP$^{3}$. Kierowała nią aż do przejścia na emeryturę w roku 1970, już na Uniwersytecie Śląskim, który powstał w roku 1968 ze scalenia WSP i katowickiej filii Uniwersytetu Jagiellońskiego. Była to druga w Polsce tego typu samodzielna Katedra - pierwszą utworzył w Wyższej Szkole Pedagogicznej w Krakowie, poprzedniczce obecnego Uniwersytetu Pedagogicznego, prof. dr hab. Włady-

${ }^{1}$ Instytut Pedagogiczny powstał w 1928 roku (uroczysta inauguracja odbyła się 28 października) jako rezultat wieloletniej kampanii wojewódzkich instancji oświatowych, towarzystw naukowych i organizacji społecznych związków oświatowych. Instytut wznowił działalność tuż po II wojnie światowej jako studium przedmiotowe o trzech kierunkach: humanistycznym z historią i polonistyką; przyrodniczym z zoologią i botaniką; nauk matematycznych z fizyką. Por. W. Zarembina: Powstanie i rozwój Wyższej Szkoły Pedagogicznej w Katowicach. W: Wyższa Szkota Pedagogiczna w Katowicach 1950-1968. Red. A. Jarosz, A. Jendrysik. Katowice 1971, s. $11-21$.

${ }^{2}$ Utworzono ją w 1946 roku, by po roku przenieść do Łodzi. Drugi raz utworzono WSP w Katowicach — w 1950 roku. Por. ibidem.

${ }^{3}$ Zob. M. Mitera-Dobrowolska: Katedra i Zakład Metodyki Nauczania Historii Literatury i Języka Polskiego. W: Wyższa Szkoła Pedagogiczna..., s. 78-88. Katedra została utworzona 1 października 1959 roku. 
sław Szyszkowski, przedwojenny wizytator ministerialny. Kierownicy obu tych Katedr współpracowali z sobą, co stanowiło w jakimś stopniu kontynuację ich kontaktów przedwojennych, kiedy Profesor Mieczysława Mitera-Dobrowolska od roku szkolnego 1932/1933 aż do wybuchu wojny prowadziła w Katowicach z sukcesem Ognisko Metodyczne Języka Polskiego dla nauczycieli województwa śląskiego. Nie sposób w tym miejscu nie zauważyć, że serdeczne stosunki łączyły też późniejszych kierowników sąsiedzkich Katedr: Profesora Zenona Urygę i Profesora Edwarda Polańskiego, co do dziś owocuje bliskimi kontaktami pracowników.

Wart przypomnienia jest też inny fakt, potwierdzający szczególną bliskość Krakowa i Katowic. Otóż w okresie wojny Profesor Mitera-Dobrowolska weszła w skład Tajnego Kuratorium Szkolnego w Krakowie, gdzie nie tylko wizytowała tajne komplety zorganizowane na terenie dystryktu krakowskiego (w Dębicy, Rzeszowie, Gorlicach, Jaśle, Sanoku, Mielcu, Tarnobrzegu, Sandomierzu), ale też zorganizowała Sekcję Śląską. W ten sposób nadal współpracowała z nauczycielami naszego regionu oraz — systemem daltońskim - kierowała pracą samokształceniową młodzieży śląskiej, którą już w czasie wojny przygotowywano do składania matury. Naturalną konsekwencją tej działalności był powojenny powrót Profesor Mitery-Dobrowolskiej z Krakowa do Katowic i podjęcie wielorakich prac w zakresie kształcenia nauczycieli polonistów.

Przyjrzyjmy się zasadom organizacji i pracy nowo utworzonej Katedry, która studentów polonistyki nie tylko miała nauczyć sztuki uczenia, ale też poszerzać ich horyzonty kulturowe i rozbudzać motywacje oraz ambicje zawodowe. Sprawą głównej wagi był dobór profesjonalnej i doświadczonej dydaktycznie kadry. Kierownik Katedry pozyskała na wstępie do pracy Jana Cofalika i Irenę Tabakowską, cenionych długoletnich polonistów z miejscowych szkół średnich, autorów pionierskiej wówczas publikacji metodycznej Kształtowanie języka ucznió $w^{4}$, którzy po pewnym czasie doktoryzowali się, specjalizując się w metodyce literatury i kultury (Cofalik) oraz w metodyce języka (Tabakowska). Podział na te dwie subdyscypliny obowiązywał także młodszą kadrę rekrutowaną zarówno spośród absolwentów (Hermenegilda Podolak-Setnikowa — 1960 i Zofia Szmytrowska-Adamczykowa - 1961), jak i zatrudnianych stopniowo wybitnych czynnych nauczycieli, między innymi: Edwarda Polańskiego (1961), Zofię Świątyńską, Elżbietę Przyklenk, a następnie Jana Polakowskiego, który wniósł do zespołu cenne doświadczenia nabyte podczas pracy w szkolnictwie zawodowym. Młodzi asystenci podejmowali także pracę w niewielkim wymiarze godzin w różnego typu szkołach (podstawowa, liceum, technikum) w celu zdobycia praktyki oraz prowadzili lekcje pokazowe dla studentów. Specjalizowali się $\mathrm{w}$ jednej z metodyk, prowadząc równocześnie — zgodnie z koncepcją

${ }^{4}$ J. Cofalik, I. Tabakowska: Ksztaltowanie języka ucznia w procesie nauczania języka polskiego. Warszawa 1963. 
kierownika Katedry — zajęcia z przedmiotów literaturoznawczych lub językoznawczych, które miały pogłębiać ich wiedzę kierunkową.

Organizując Katedrę, wyznaczała jej Profesor Dobrowolska ambitne i szeroko zakreślone cele. Współpracowała z ministerialną komisją rzeczoznawców, między innymi w zakresie siatek studiów, dzięki czemu wprowadziła do Katedry nowe przedmioty, takie jak: historię sztuki, literaturę dla dzieci i młodzieży oraz kulturę żywego słowa, pozyskała specjalistów do ich prowadzenia. Historię sztuki wykładał początkowo dydaktyk z Krakowa, następnie dr Zofia Maślińska-Nowakowa (historyk sztuki, a zarazem polonistka, związana z Katedrą aż do emerytury). Z kolei kultury żywego słowa uczył dr Marian Mikuta, znany aktor i polonista, autor cenionego podręcznika z tego zakresu: Kultura żywego słowa ${ }^{5}$. W zakresie literatury dla dzieci i młodzieży, o której włączenie w tok studiów walczyła kierownik Katedry wespół z prof. dr hab. Izabelą Kaniowską-Lewańską, wówczas zatrudnioną w Wyższej Szkole Pedagogicznej w Opolu, oraz z prof. dr hab. Krystyną Kuliczkowską z Uniwersytetu Warszawskiego, zaczęły specjalizować się Zofia Świątyńska i Zofia Adamczykowa, podejmując tematy doktorskie $\mathrm{z}$ tego zakresu. Te nowe przedmioty włączone do Katedry poszerzały kompetencje zawodowe przyszłych nauczycieli polonistów, a zarazem zakres oddziaływania Katedry na studentów.

Należy przypomnieć, że z końcem lat pięćdziesiątych ubiegłego stulecia metodyka nauczania budziła liczne kontrowersje jako samodzielna dyscyplina naukowa, toteż kierownik Katedry postulowała uznanie metodyk za pełnoprawne dyscypliny, w których zakresie byłoby możliwe zdobywanie kolejnych stopni naukowych. Wciąż słała do Warszawy memoriały w tej sprawie. Jej starania w tym zakresie, wsparte przez inne ośrodki akademickie, odniosły pożądany skutek. Pozyskała dla tej idei ówczesnego ministra Henryka Jabłońskiego, który w roku 1967 Zarządzeniem nr UE-1990-23-67 otwierał możliwość awansu naukowego w tej dziedzinie. Stworzyło to korzystne warunki dla pierwszego w Polsce seminarium doktorskiego o profilu polonistyczno-dydaktycznym, jaki prowadziła Pani Profesor przy katowickiej Katedrze w latach 1963-1973. Pionierski charakter seminarium oraz serdeczna atmosfera spotkań ściągały uczestników z odległych miast: Krakowa, Opola, Gdańska, Warszawy, Poznania, Bydgoszczy, Cieszyna, integrując zespół młodszej kadry akademickiej z różnych ośrodków oraz czynnych nauczycieli. Efektem pracy tego seminarium było wypromowanie kilkunastu doktorów, z których kilkoro uzyskało kolejne stopnie naukowe.

Do awansów naukowych przywiązywała kierownik Katedry dużą wagę, toteż na zebraniach, które odbywały się co piątek, pracownicy nie tylko omawiali problemy dydaktyczne oraz zdawali sprawozdania z przydzielonych im zadań pozadydaktycznych, ale też zawsze przedstawiali swoje plany naukowe.

${ }^{5}$ M. Mikuta: Kultura żywego stowa. Warszawa 1961. 
Wypowiadali się zarówno członkowie Katedry, najczęściej referując fragmenty powstających własnych prac doktorskich, jak i zapraszani goście reprezentujący pokrewne dyscypliny naukowe (psycholodzy, historycy literatury, językoznawcy), często z innych ośrodków, co stwarzało młodej kadrze zarówno możliwość wejścia w różnorakie nurty badań naukowych, jak i nawiązania kontaktów z wybitnymi uczonymi. Taką samą funkcję spełniały wyjazdy na liczne konferencje naukowe w kraju, z których pracownicy chętnie korzystali, a także organizowali własne. Katedra utrzymywała nadto żywe kontakty z innymi uczelniami pedagogicznymi w Polsce, zwłaszcza w Krakowie, w Opolu i w Gdańsku, ale też ze studiami nauczycielskimi, między innymi w Zgierzu, Piotrkowie Trybunalskim czy w Zielonej Górze. Ponadto - jeżeli to w tamtych czasach było możliwe nawiązywano kontakty zagraniczne z uczelniami pedagogicznymi w Wilnie, Poczdamie, Budziszynie (Łużyce), skąd zapraszano prelegentów, wymieniano się publikacjami, zwłaszcza podręcznikami szkolnymi.

W procesie kształcenia zawodowego studentów szczególną rolę przypisywano praktykom przedmiotowo-metodycznym, które starannie przygotowywano, dbając o wyeliminowanie wszelkiej przypadkowości. Utrzymywano w tej sprawie stały kontakt z Kuratorium Oświaty, skąd pozyskiwano informacje o szkołach i wybitnych polonistach, których warto uwzględnić w tzw. rozdzielniku praktyk, jaki sporządzano wnikliwie, uwzględniając postępy studentów w przedmiocie, a nawet miejsca ich zamieszkania. Wszyscy pracownicy włączali się w hospitacje praktyk, ich wyniki omawiano na zebraniach wewnętrznych, a po zakończeniu praktyk — na zebraniu ogólnym. Opinie z praktyk były rzetelnie analizowane, o czym świadczyły przypadki braku ich zaliczenia.

Warto podkreślić, że pracownicy Katedry utrzymywali żywe kontakty nie tylko z miejscowym Kuratorium Oświaty, ale też z nauczycielami, którzy świadczyli Katedrze usługi w ramach praktyk śródrocznych i ciągłych, prowadzili dla studentów lekcje pokazowe i zajęcia pozalekcyjne. Byli oni zapraszani na zebrania naukowe Katedry, na odczyty i konferencje. Oprócz wydawanych przez Katedrę Zeszytów Naukowych podjęto się opracowania specjalnie dla czynnych nauczycieli obszernej publikacji pod znamiennym tytułem $Z$ pomoca poloniście, która miała być wydawnictwem seryjnym. Wydano jednakże tylko dwa numery - po utworzeniu Uniwersytetu Śląskiego publikacji nie kontynuowano.

W Katedrze zapewniono studentom szeroką bazę zarówno dla praktyk śródrocznych, jak i ciągłych. Zorganizowano pracownię polonistyczną wyposażoną w specjalistyczny księgozbiór, który sukcesywnie gromadzono od początków istnienia Katedry, bardzo obszerny zbiór reprodukcji malarskich, wykorzystywanych także do zajęć z historii sztuki, albumów oraz nowoczesny wówczas sprzęt audiowizualny, pły totekę, magnetofonowe nagrania lekcji oraz inne środki dydaktyczne. Jak wielką rolę przywiązywała kierownik Katedry do zorganizowanej pracowni, świadczy fakt, że przekazała jej część zbiorów prywatnych, 
z pierwszymi wydaniami Pana Tadeusza i Konrada Wallenroda włącznie. Studenci — pod kierunkiem pracowników z Wydziału Matematyczno-Fizyczno-Chemicznego (tak on się wtedy nazywał) - przechodzili w Katedrze kursy obsługi sprzętu audiowizualnego, który był w latach sześćdziesiątych minionego stulecia nowością, w dodatku mało dostępną. Chodziło bowiem o przygotowanie przyszłych polonistów do realizacji zalecanej wówczas w programach szkolnych audiowizualizacji procesu nauczania.

W trosce o wszechstronne przygotowanie zawodowe studentów Katedra organizowała również wycieczki studenckie. Były to wycieczki o charakterze naukowym (np. do bibliotek naukowych, do muzeów), polonistycznym (np. śladami pisarzy) lub wybitnie dydaktycznym (do szkół technicznych, sanatoryjnych czy do eksperymentujących nauczycieli). W każdym wypadku wymagały one przygotowania merytorycznego zarówno ze strony nauczycieli akademickich, jak i studentów. Dodajmy, że organizacja owych wycieczek była możliwa z uwagi na nieliczne wówczas roczniki studenckie, które liczyły średnio czterdzieści osób.

Przy Katedrze utworzono także Teatr Studencki, który przyszłym nauczycielom miał dostarczyć wzorca do jednej z form pracy pozalekcyjnej. Prowadził go z sukcesem specjalista od kultury żywego słowa — dr Marian Mikuta. Teatr działał przez wiele lat i był swoistą szkołą kształcenia polonistycznego, kulturowego i zawodowego. Wystawiono wiele ambitnych spektakli w środowisku akademickim oraz poza nim. Teatr odnosił również sukcesy w konkursach ogólnopolskich. Wykształcił też kilku pasjonatów, późniejszych działaczy kulturalno-oświatowych, a nawet aktora.

W Katedrze zrodziła się też koncepcja wprowadzenia nowych form egzaminów wstępnych, które sprawdzałyby nie tylko wiedzę kandydatów, ale także ich sprawności i predyspozycje do wybranego kierunku studiów. Wprowadzono więc do egzaminu pisemnego polecenia analizy i interpretacji wskazanych tekstów poetyckich, opracowania konspektów z żywych czy odsłuchanych z nagrania wykładów lub z fragmentu tekstu naukowego, sprawdziany z dykcji i z ortografii. Nie ulega wątpliwości, że z tych koncepcji wyrosły późniejsze formy egzaminów na filologię polską na Uniwersytecie Śląskim, a i na innych uczelniach podejmowano podobne eksperymenty $\mathrm{w}$ tym zakresie.

Dążąc do podniesienia jakości studiów, eksperymentowano też w zakresie form egzaminów końcowych z przedmiotów metodycznych. Próbowano powiązać teorię z praktycznymi działaniami studentów, którzy mając do dyspozycji materiały zgromadzone w pracowni, przygotowywali konspekt lekcji na zadany temat. Wydłużało to wprawdzie czas egzaminu, ale pozwalało na pełniejszą diagnozę egzaminacyjną. Powtórzę, że roczniki studenckie były wówczas nieliczne. Pozwalało to również utrzymywać kontakty z absolwentami. W roku 1963 utworzono Wydziałową Komisję do spraw Zatrudniania Absolwentów, której przewodniczyła kierownik Katedry. Pracownicy organizowali zjazdy 
absolwentów, a także podejmowali badania dotyczące ich zawodowych losów i osiągnięć oraz potrzeb rynku pracy dla magistrów filologii polskiej. Wyniki tych badań próbowano powiązać z limitami przyjęć na studia polonistyczne.

W Katedrze koncentrowała się też w latach 1960-1973 działalność Towarzystwa Literackiego im. Adama Mickiewicza, które istniało na Śląsku od roku 1928. Prezesem Oddziału była kierownik Katedry, sekretarzem — Edward Polański, skarbnikiem - Zofia Adamczykowa. Działalność Oddziału obejmowała w głównej mierze wykłady i odczyty, na które zapraszano wybitnych naukowców z różnych ośrodków akademickich w Polsce, uwzględniając bieżące potrzeby środowiska polonistycznego. W dniach 8-12 października 1964 roku zorganizowano w Katowicach kilkudniowy ogólnopolski zjazd Towarzystwa, który wysoko ocenił jego ówczesny Zarząd Główny.

$\mathrm{Z}$ biegiem czasu, wraz ze zwiększaniem się liczby studentów, przybywało do Katedry pracowników, rzadko spoza naszego regionu, jak Anna Opacka, rekrutujących się głównie spośród wyróżniających się absolwentów, którzy stopniowo zdobywali kolejne stopnie naukowe, aż po profesury. Stanowią oni dzisiaj trzon Katedry: Ewa Ogłoza, Helena Synowiec, Ewa Jaskółowa, Bernadeta Niesporek-Szamburska, Danuta Krzyżyk, Olga Przybyla, Anna Guzy, Małgorzata Wójcik-Dudek, Krystyna Koziołek, Karolina Starnawska, Magdalena Ochwat, a zespół ten powiększa się nieustannie o młodych doktorantów. Ponadto w Katedrze — krócej lub dłużej — pracowali: Urszula Żydek-Bednarczuk, Bogdan Zeler, Maria Bralczyk-Karolakowa, Monika Pasztowa, Bożena Witoszowa, Krystyna Orłowa, Jerzy Budzik, Jolanta Małuszyńska, Aleksandra Pethe, Elżbieta Dutka, Bożena Cząstka-Szymonowa, Wiga Bednarkowa, Gotfryd Pyka, Halina Gorczycowa, Janina Zdyb, Jan Andrzej Fręś. Każda z tych osób wnosiła do Katedry zarówno cząstkę własnej osobowości, jak i odmienne doświadczenia pedagogiczne oraz indywidualne zainteresowania naukowe. Nie przeczę, że mogłam tu kogoś pominąć. Z pewnością nie pamiętam już pań, które sekretarzowały w Katedrze przez te wszystkie lata. Ale jedno wiem - niezastąpioną od wielu lat podporą Katedry była do końca mgr Anna Jankowska, która - nawet bez komputera - panuje nad wszystkim.

Od roku 1968 Katedra funkcjonowała już na Uniwersytecie Śląskim, kontynuując sprawdzone formy pracy i uwzględniając wymogi czasu. Kierowali nią kolejno od roku 1970: dr Jan Cofalik, najdłużej - prof. dr hab. Edward Polański, następnie przez dwa lata - prof. dr hab. Anna Opacka, potem prof. dr hab. Helena Synowiec, obecnie - prof. dr hab. Ewa Jaskółowa ${ }^{6}$. Przez

${ }^{6}$ Ewa Jaskółowa kierowała Katedrą do końca jej działalności, czyli do 30 września 2019 roku, kiedy nastąpiła likwidacja Katedry w związku ze zmianą struktury Uniwersytetu Śląskiego. Dla porządku wymienię wszystkich kierowników Katedry i lata ich działania: Mieczysława Mitera-Dobrowolska — kierownik w latach 1959-1971, Jan Cofalik — w latach 1971-1973, Edward Polański — w latach 1973 - 2002, Anna Opacka — w latach 2002 - 2004, Helena Synowiec — w latach 2004 — 2012, Ewa Jaskółowa — od 2012 roku do końca funkcjonowania Katedry. 
te wszystkie lata podejmowano w Katedrze badania indywidualne i zespołowe, których wyniki publikowano. Organizowano liczne konferencje naukowe zwieńczone publikacjami. Od roku 1977 do dziś wydawany jest rocznik pt. „Z Teorii i Praktyki Dydaktycznej Języka Polskiego”. Najpierw redagował go Profesor Edward Polański, następnie przejęła tę funkcję Profesor Helena Synowiec, obecnie - dr hab. Danuta Krzyżyk, prof. UŚ. Dorobek naukowy Katedry oraz współczesne osiągnięcia jej pracowników w wymiarze indywidualnym, regionalnym, ale też krajowym i zagranicznym są ogromne, toteż wymagałyby osobnego omówienia. O jednym wszakże wspomnę. Zdarzało się, że angażowano pracowników w prace zbędne, jak wielokierunkowe badania wdrożeniowe dotyczące dziesięciolatki, z której wprowadzenia władze się wycofały, co dobitnie świadczy o niefortunnych próbach reform w szkolnictwie, z czym wciąż mamy do czynienia.

Na koniec chcę powiedzieć parę słów o wyjątkowym „duchu” Katedry, który trwa niezmiennie przez sześćdziesiąt lat mimo licznych zmian strukturalnych i personalnych. Narodził się on w początkach istnienia Katedry dzięki wyjątkowej postawie Profesor Mieczysławy Mitery-Dobrowolskiej, która nie tylko była niezwykle zaangażowana w prace Katedry i konsekwentnie realizowała ambitne cele w zakresie nowoczesnego kształcenia nauczycieli polonistów, ale była też serdeczna, przychylna ludziom i zawsze wsłuchana w to, co przynosił jej rozmówca. Swoistym fenomenem tamtych lat była atmosfera cotygodniowych zebrań naukowych Katedry, które zwykle składały się z części towarzyskiej skoncentrowanej na kalendarium imieninowo-rocznicowo-urodzinowym. Najbardziej uroczysty charakter miały spotkania powakacyjne i noworoczne. Te ostatnie wiązały się z urodzinami i imieninami szefowej, które przypadały na Nowy Rok. Towarzyszyła im specjalnie na tę okazję pisana przez Doktor Irenę Tabakowską noworoczna szopka katedralna, stanowiąca podsumowanie całorocznych zmagań, osiągnięć i porażek. Z czasem, za sprawą owych szopek, pracownicy Katedry używali wobec siebie imion „osób dramatu”, co było niewątpliwie elementem integrującym, wzmacniającym serdeczne więzi ${ }^{7}$. Podobnie jak wspólne wycieczki i wyjazdy o charakterze na poły zawodowym, na poły towarzyskim, na przykład do Korwinowa koło Częstochowy, gdzie mieścił się dom rodzinny prof. dr. hab. Jana Polakowskiego. Cementowały one ze-

7 Powstała kronika Katedry prowadzona do lat siedemdziesiątych, w którą wpisywano poza odnotowywaniem wydarzeń teksty wierszowane o bohaterach ,dramatu”, np. pod datą 18 marca 1965 roku zapisano tekst kierowany do profesora Edwarda Polańskiego, wtedy jeszcze magistra: Wykładów Ładzicielu tudzież Sekretarzu / Katedry i cytryn Szafarzu! / Nasz sal dystrybutorze $i$ westchnień przedmiocie / Ptci nadobnej w Katedrze, co dotrwała w cnocie... / Wycieczek zagranicznych organizatorze, / Łużyc region głębiacy nawet w nocnej porze! / Co Ci życzyć dziś mamy $w$ dniu patrona Twego? / Więc primo powodzenia i zdrowia dobrego, / Secundo - doktoratu, tertio - szczęścia wiele, / Niechaj zawsze w pieleszach Twych gości wesele, / byś nie zaznat ni zmartwień, ni życia goryczy, / Tego Ci konfraternia metodyków życzy. 
spół, utrwalały poczucie wspólnoty i odpowiedzialności za sprawy katedralne, wzmacniały postawy zaangażowania. Dziś nazwalibyśmy je wyjazdami integracyjnymi.

A więc jeśli obecnie nasi młodsi koledzy (nieżyjąca Pani Profesor powiedziałaby: moi młodzi przyjaciele) zapraszają Profesora Edwarda Polańskiego i mnie, emerytów o kilkunastoletnim stażu, na swoje zebrania naukowe z częścią towarzyską, przepełnioną wzajemną życzliwością i serdecznością, czuję tę aurę sprzed ponad pół wieku i cieszy mnie, że ten dobry duch Katedry nieustannie trwa. Oby udało się go zachować w tych nieuniknionych — jak sądzę — nowych formach organizacyjnych. Wierzę, że to się uda, bo atmosferę tworzą przecież nie miejsca czy struktury, lecz sami ludzie.

\section{Bibliografia}

Cofalik J., Tabakowska I.: Kształtowanie języka ucznia w procesie nauczania języka polskiego. Warszawa 1963.

Mikuta M.: Kultura żywego stowa. Warszawa 1961.

Mitera-Dobrowolska M.: Katedra i Zaktad Metodyki Nauczania Historii Literatury i Języka Polskiego. W: Wyższa Szkoła Pedagogiczna w Katowicach 1950-1968. Red. A. Jarosz, A. Jendrysik. Katowice 1971.

Zarembina W.: Powstanie i rozwój Wyższej Szkoły Pedagogicznej w Katowicach. W: Wyższa Szkota Pedagogiczna w Katowicach 1950-1968. Red. A. Jarosz, A. Jendrysik. Katowice 1971. 